\title{
EFFECT OF PYRIPROXYFEN AND DIAFENTHIURON COMMARED WITH MELBIMECTIN ON THE COTTON LEAFWORM, SPODOPTERA LITTORALIS
}

\author{
MOHSEN MOHAMED ALI
}

Plant Protection Research Institute, ARC, Dokki, Giza

(Manuscript received 22 May 2008)

\begin{abstract}
Under laboratory conditions the initial, latent effect and biometric effects of two IGR's pyriproxyfen (Admiral) and diafenthiuron (Polo) and melbimectin (biocide) were studied on the $6^{\text {th }}$ instar larvae of the cotton leafworm, Spodoptera littoralis (Boisd.) of pyriproxyfen was the most effective, it caused $101.56 \%$ increase in duration of the $6^{\text {th }}$ instra larval, followed by diafenthiuron at the recommended rate gave $73.77 \%$ increase, in contrast melbimectin was ineffective when all the three chemicals tested at the recommended rate of each. Pyriproxyfen was the most potent compound in increasing the weight of treated larvae (46.15\% increase), while diafenthiuron and melbimectin reduced the larval weight (33.33 and $20.51 \%$ decrease, respectively). Melbimectin was highly effective against larval stage, where mortality percentages ranged from 30.3 to 54.5 after 48 hrs of treatment. While, it was ineffective during pupal stage, recording from 0.0 to $5.0 \%$ mortality. On the other hand, pyriproxyfen and diafenthiuron exhibited poor effect against larval stage, while they were potent during pupal stage. The highest reduction pupation percentages were $(38,52$ and $56 \%$ pupation), for melbimectin, diafenthiuron and pyriproxyfen, respectively. However, pyriproxyfen was superior to melbimectin and diafenthiuron in forming abnormal pupae. In this respect, pyriproxyfen at the rates 75 and $37.5 \mathrm{ppm}$ exhibited the highest percent pupal malformation ( $75.00 \%$ and $76.32 \%$, respectively). Melbimectin at the rate of 75 $\mathrm{ppm}$ and diafenthiuron at the rate of $1500 \mathrm{ppm}$ gave 57.89 and $50.00 \%$ pupal malformation, respectively. Pyriproxyfen reduce moths emergence (23.68-50.00\%), while diafenthiuron (50.00$89.19 \%)$ and melbimectin recorded $42.11-93.33 \%$ with different concentrations.
\end{abstract}

\section{INTRODUCTION}

The cotton leafworm, Spodoptera littoralis (Boisd.) is considered a serious polyphagous noctuid pest on several agricultural important crops, including cotton, in Egypt. Depending mainly on chemical control methods by extensive use of various insecticides had led to resistance to most groups of conventional insecticides. During the last 3 decades extensive investigation efforts is being made for development of unconventional effective control materials with new modes of action, against this pest. One of such new groups is the insect growth regulators (IGR's) that interfere with moulting process (Mulder and Gijswijt, 1973, Mituis, 1985). 
However, more selective, insect growth inhibitors (IGI's) and regulators (IGR's) have become increasingly available in the last decade. Therefore, the present study was aiming to evaluate the biological activity, either initial or residual effects and biometrics effects of two IGR's including the thiourea derivative diafenthiuron, and the juvenoids compound pyriproxyfen, in addition to a biocide product, melbimectin against the $6^{\text {th }}$ instar larvae of the cotton leafworm, $S$. littoralis (Boisd.).

\section{MATERIALS AND METHODS}

\section{a. Source of insects:}

Laboratory strain of $S$. littoralis was reared under the laboratory conditions of Sakha Agricultural Research Station for over 20 generations according to the method of El-Defrawi et al. (1964).

\section{b. Pesticides:}

\section{Insect growth regulators (IGR's):}

\section{a. Pyriproxyfen (Admiral 10\% EC):}

4-phenoxyphenyl (RS)-2-(2-pyridyloxy) propyl ether at rate of 75, 37.5, 18.8 and 9.4 ppm.

\section{b. Diafenthiuron (Polo 50\% SC):}

1-teret butyl-3(2,6-di-isopropyl-4-phenoxyphenyl) thiourea, at rate of 1500, 750, 375 and $187.5 \mathrm{ppm}$.

\section{Biocide:}

\section{a. Melbimectin (CM006 1\% EC):}

Natural product (metabolite) produced through fermentation of soil microorganism, Streptomyces hygroscopicus at rates of 75, 37.5, 18.8 and 9.4 ppm.

\section{Testing procedure:}

To study the initial and latent effect activity of pyriproxyfen, diafenthiuron and melbimectin against $S$. littoralis, recommended, $1 / 2,1 / 4$ and $1 / 8$ recommended rates of each compound were prepared using tap water in dilutions. Castor bean leaves were dipped in each prepared solution for ten seconds, and then left under laboratory conditions till complete dryness. Ten replicates for each concentration were prepared where five $6^{\text {th }}$ instar larvae were confined in a $(1 \mathrm{lb})$ plastic jar as a replicate. The larvae were fed on fresh treated leaves for 24 hrs and then replaced by untreated ones till pupation. Survival larvae of each replicate were weighted daily. Ten replicates were used as control where larvae were fed on untreated leaves. The plastic jars were replaced with clean ones daily till pupation and pupae were transferred and kept in cages for adult emergence. Dead larvae were recorded daily and mortality percentages were corrected according to Abbott's formula (1925). Also, percent 
mortality during pupal stage, percent pupation, pupal malformation percentages and percent of moths emergence were estimated using formula suggested by Toppozada et al. (1966).

\section{RESULTS AND DISCUSSION}

\section{Mortality during larval and pupal stages:}

Data in Table (1) indicated that although the biocide melbimectin was the highly effective tested compound against larval stage and gave appreciable mortality ranged from 30.3 to 54.5 after 48 hrs of treatment, nevertheless it was completely noneffective during pupal stage, exhibiting mortality ranging between 0.0-5.0. On contrary, pyriproxyfen and diafenthiuron exhibited poor effect against larval stage (percent mortality ranged from 0.0 to 12.12 ) for both compounds, while potent effect appeared during pupal stage mainly at the recommended rates of each, reaching 40.43 and $33.33 \%$ mortality, respectively.

These results are in agreement with that of Korkor et al. (1961), they reported that 5 days post-treatment of the $4^{\text {th }}$ instar larvae of cotton leafworm IGR (methoprene) caused less mortality $(32.7 \%)$, than IDI's which caused $100 \%$ mortality during the same period.

\section{Effect on percent pupation and pupal malformation:}

Results in Table (2) showed that the most effective treatment in reducing pupation percentages was melbimectin (38\% pupation), followd by diafenthiuron (52\% pupation) and pyriproxyfen (56\% pupation), respectively at the recommended rate of each, compared with normal percent pupation of $96 \%$ in control.

Regarding the effect on pupal malformation, pyriproxyfen showed the highest effect in forming abnormal pupae resulted from treated the $6^{\text {th }}$ instar larvae of $S$. littoralis. However, pyriproxyfen at the rates of 75 and $37.5 \mathrm{ppm}$ exhibited the highest percent pupal malformation $(75.00 \%$ and $76.32 \%$, respectively) without significant differences in between. melbimectin at the rate of $75 \mathrm{ppm}$ and diafenthiuron at the rate of 1500 ppm were as effective equal pyriproxyfen at the lowest rate, $9.4 \mathrm{ppm}$, pupal malformation were $57.89,50.00 \& 50.00 \%$, respectively.

However, diafenthiuron and melbimectin at their other three decreasing tested rates resulted (low pupal malformation\%, it ranged between (6.67-16.23) and (from 23.08 to 10.81 ), respectively compared with $10.42 \%$ ) pupal malformation in untreated check (control). Shaaban and Mourad (1994) stated that treatment of cotton leafworm larvae at different instars with flufenoxuron obviously reduced normal pupation and inhibited adult emergence. 


\section{Effect on normal moths emergence:}

Data in Table (2) showed that the treatments under test could be arranged descendingly according to their efficiency in reducing normal moths emergence as follows, pyriproxyfen (25.0-50.0\%), diafenthiuron (50.00-76.92\%) and melbimectin (42.11-93.33\%), compared with $89.58 \%$ in control. These findings were similar to the results of Abd El-Naby et al. (1988), they reported that triflumuron and chlorfluazuron (IGR's) caused reduction in pupation and emergence of adult moths. These results agree with the finding Moawad et al. (1996) who reported that treating egg masses of S. littoralis by dipping technique resulted $77.6^{\circ}{ }^{\circ}$ non emerged moth.

\section{Effect on larval longevity:}

Data in Table (3) showed that pyriproxyfen at the field recommended rate (75 ppm) was the most effective in this respect, where it caused $101.56 \%$ increase in duration of the $6^{\text {th }}$ instra larvae compared with untreated (check) (mean longevity of larvae was $(7.76 \pm 3.56)$ pyriproxyfen versus $(3.85 \pm 0.24)$ days for untreated (check). Diafenthiuron at the recommended rate $(1500 \mathrm{ppm})$ was as effective as pyriproxyfen at $37.5 \mathrm{ppm}$ (73.77\% increase in larval period).

Table 1. Initial and accumulative activity of biocide and two IGR's against the $6^{\text {th }}$ instar larvae and pupale stage of $S$. littoralis under laboratory conditions.

\begin{tabular}{|c|c|c|c|c|}
\hline \multirow[t]{2}{*}{ Tested compounds } & \multirow[t]{2}{*}{ Ppm } & \multicolumn{2}{|c|}{$\begin{array}{c}\% \text { Corrected larval mortality post- } \\
\text { treatment at }\end{array}$} & \multirow[t]{2}{*}{ \%Pupal mortality } \\
\hline & & $24 \mathrm{hrs}$ & 48 hrs & \\
\hline \multirow{4}{*}{$\begin{array}{c}\text { Pyriproxyfen } \\
\text { (Admiral 10\% EC) }\end{array}$} & 75 & $0.0^{\mathrm{a}}$ & $1.01^{\mathrm{ab}}$ & $40.73^{9}$ \\
\hline & 37.5 & $0.0^{\mathrm{ab}}$ & $5.05^{\mathrm{b}}$ & $15.56^{\text {ed }}$ \\
\hline & 18.8 & $0.0^{\mathrm{a}}$ & $3.03^{\mathrm{ab}}$ & $13.33^{\text {ed }}$ \\
\hline & 9.4 & & $0.0^{\mathrm{a}}$ & $18.38^{\mathrm{de}}$ \\
\hline \multirow{4}{*}{$\begin{array}{l}\text { Diafenthiuron (Polo } \\
50 \% \mathrm{SC} \text { ) }\end{array}$} & 1500 & $4.0^{\mathrm{ab}}$ & $12.12^{\mathrm{e}}$ & $33.33^{f}$ \\
\hline & 750 & $0.0^{\mathrm{a}}$ & $0.0^{\mathrm{a}}$ & $21.28^{\mathrm{e}}$ \\
\hline & 375 & $0.0^{\mathrm{a}}$ & $2.0^{\mathrm{ab}}$ & $4.26^{\mathrm{ab}}$ \\
\hline & 187.5 & $6.0^{\mathrm{b}}$ & $9.09^{e}$ & $9.30^{\text {be }}$ \\
\hline \multirow{4}{*}{$\begin{array}{c}\text { Melbimectin } \\
\text { (CM006 1\% EC) }\end{array}$} & 75 & $54.0^{e}$ & $54.5^{f}$ & $5.00^{\mathrm{a}}$ \\
\hline & 37.5 & $28.0^{\mathrm{e}}$ & $30.3^{d}$ & $3.13^{\mathrm{a}}$ \\
\hline & 18.8 & $32.0^{\text {ed }}$ & $36.4^{e}$ & $0.00^{\mathrm{a}}$ \\
\hline & 9.4 & $36.0^{\mathrm{d}}$ & $37.4^{\mathrm{e}}$ & $0.00^{a}$ \\
\hline $\begin{array}{c}\text { Control } \\
\text { (untreated) }\end{array}$ & water & - & 2 & $2.04^{a}$ \\
\hline
\end{tabular}

In the same column, means followed by a common letter are not significantly different at the $5 \%$ level by Duncan (1955). 
Table 2. Biometric effects of biocide and two IGR's during pupal stage of 50 treated the $6^{\text {th }}$ instar larvae of $S$. littoralis.

\begin{tabular}{|c|c|c|c|c|c|c|c|}
\hline $\begin{array}{c}\text { Tested } \\
\text { compounds }\end{array}$ & ppm & $\begin{array}{l}\text { No. alive } \\
\text { larvae }\end{array}$ & $\begin{array}{c}\% \\
\text { pupation }\end{array}$ & $\begin{array}{l}\text { No. of } \\
\text { normal } \\
\text { pupae }\end{array}$ & $\begin{array}{c}\text { No. of } \\
\text { abnormal } \\
\text { pupae }\end{array}$ & $\begin{array}{c}\text { \%pupal } \\
\text { malformation }\end{array}$ & $\begin{array}{c}\text { \%normal } \\
\text { moths } \\
\text { emergence }\end{array}$ \\
\hline \multirow{4}{*}{$\begin{array}{l}\text { Pyriproxyfen } \\
\text { (Admiral } 10 \% \\
\text { EC) }\end{array}$} & 75 & 49 & $56^{\mathrm{e}}$ & 7 & 21 & $75.00^{\mathrm{a}}$ & $25.00^{e}$ \\
\hline & 37.5 & 48 & $76^{\mathrm{bcd}}$ & 9 & 29 & $76.32^{\mathrm{a}}$ & $23.68^{\mathrm{e}}$ \\
\hline & 18.8 & 49 & $78^{\mathrm{bc}}$ & 13 & 26 & $66.67^{b}$ & $33.33^{\mathrm{de}}$ \\
\hline & 9.4 & 50 & $80^{\mathrm{b}}$ & 20 & 20 & $50.00^{d}$ & $50.00^{e}$ \\
\hline \multirow{4}{*}{$\begin{array}{l}\text { Diafenthiuron } \\
\text { (Polo } 50 \% \text { SC) }\end{array}$} & 1500 & 44 & $52^{e f}$ & 13 & 13 & $50.00^{d}$ & $50.00^{e}$ \\
\hline & 750 & 50 & $74^{\text {bed }}$ & 33 & 4 & $10.81^{\mathrm{fg}}$ & $89.19^{\mathrm{ab}}$ \\
\hline & 375 & 49 & $90^{\mathrm{ab}}$ & 34 & 11 & $24.44^{\mathrm{e}}$ & $75.56^{\mathrm{b}}$ \\
\hline & 187.5 & 46 & $78^{\mathrm{bc}}$ & 30 & 9 & $23.08^{c}$ & $76.92^{\mathrm{ab}}$ \\
\hline \multirow{4}{*}{$\begin{array}{c}\text { Melbimectin } \\
\text { (CM006 1\% EC) }\end{array}$} & 75 & 23 & $38^{f}$ & 8 & 11 & $57.89^{\mathrm{e}}$ & $42.11^{\mathrm{ed}}$ \\
\hline & 37.5 & 35 & $62^{\mathrm{de}}$ & 26 & 5 & $16.23^{f}$ & $83.77^{\mathrm{ab}}$ \\
\hline & 18.8 & 32 & $60^{\mathrm{de}}$ & 27 & 3 & $10.00^{\mathrm{fg}}$ & $90.00^{\mathrm{ab}}$ \\
\hline & 9.4 & 32 & $60^{\text {de }}$ & 28 & 2 & $6.67^{9}$ & $93.33^{\mathrm{a}}$ \\
\hline Control & Water & - & $96^{\mathrm{ab}}$ & 43 & 5 & $10.42^{\mathrm{fg}}$ & $89.58^{\mathrm{ab}}$ \\
\hline
\end{tabular}

In the same column, means followed by a common letter are not significantly different at the $5 \%$ level by Duncan (1955).

Table 3. Effect of biocide and two IGR's on longevity and weight of treated the $6^{\text {th }}$ larval instar of $S$. littoralis.

\begin{tabular}{|c|c|c|c|c|c|}
\hline \multirow{4}{*}{ Tested compounds } & Ppm & $\begin{array}{c}\text { Larval duration } \\
\text { (days) } \\
\text { Mean } \pm \text { SE }\end{array}$ & $\begin{array}{c}\text { \%Change in larval } \\
\text { longevity than } \\
\text { control }\end{array}$ & $\begin{array}{c}\text { Larval weight } \\
\text { (grams) } \\
\text { Mean } \pm \text { SE }\end{array}$ & $\begin{array}{c}\text { \%Change in } \\
\text { larval weight } \\
\text { than control }\end{array}$ \\
\hline \multirow{4}{*}{$\begin{array}{c}\text { Pyriproxyfen } \\
\text { (Admiral 10\% EC) }\end{array}$} & 75 & $7.76 \pm 0.356$ & 101.56 & $0.57 \pm 0.017$ & 46.15 \\
\cline { 2 - 6 } & 37.5 & $6.74 \pm 0.290$ & 75.06 & $0.50 \pm 0.011$ & 28.21 \\
\cline { 2 - 6 } & 18.8 & $5.82 \pm 0.661$ & 51.17 & $0.46 \pm 0.013$ & 17.85 \\
\hline \multirow{3}{*}{$\begin{array}{c}\text { Diafenthiuron (Polo } \\
\text { 50\% SC) }\end{array}$} & 750 & $4.73 \pm 0.154$ & 22.86 & $0.41 \pm 0.013$ & 5.13 \\
\cline { 2 - 6 } & 375 & $5.80 \pm 0.200$ & 50.65 & $0.36 \pm 0.013$ & -7.69 \\
\cline { 2 - 6 } & 187.5 & $5.83 \pm 0.258$ & 51.43 & $0.33 \pm 0.008$ & -15.38 \\
\hline \multirow{2}{*}{$\begin{array}{c}\text { Melbimectin } \\
\text { (CM006 1\% EC) }\end{array}$} & 75 & $3.85 \pm 0.518^{*}$ & 0.00 & $0.31 \pm 0.021 *$ & -20.51 \\
\cline { 2 - 6 } & 37.5 & $4.84 \pm 0.232$ & 25.71 & $0.42 \pm 0.019$ & 7.69 \\
\cline { 2 - 6 } & 18.8 & $3.65 \pm 0.442$ & -5.18 & $0.43 \pm 0.017$ & 10.26 \\
\hline \multirow{2}{*}{$\begin{array}{c}\text { Control } \\
\text { (untreated) }\end{array}$} & 9.4 & $3.69 \pm 0.638$ & -4.16 & $0.43 \pm 0.022$ & 10.26 \\
\hline
\end{tabular}


On contrary, melbimectin at the recommended rate $(75 \mathrm{ppm})$ as expected do not exhibited any influence on the longevity of the treated $6^{\text {th }}$ instra larvae, while the rates 18.8 and $9.4 \mathrm{ppm}$ resulted in reduction of the larval longevity in comparison to untreated larvae.

These results agreed fully with that of Moawad et al. (1996) found that life time of treated larvae on cotton leafworm was longer than control when pyriproxyfen and KZoil were used against eggs of S. littoralis. Also, Zidan et al. (1996) stated that pyriproxyfen (Admiral) prolonged larval duration, adult longevity and decreased pupal weight of $S$. littoralis.

\section{Effect on larval weight:}

Results in Table (3) indicated that pyriproxyfen was the only potent compound in increasing the weight of treated the $6^{\text {th }}$ instar larvae of $S$. littoralis, exhibiting $46.15 \%$ increase in comparison to control larvae, while the rest three tested rates showed increase in larval weight percentages ranged from 10.26 to 28.21 . On the other hand, diafenthiuron and melbimectin revealed decrease in larval weight than control particularly, at the recommended rate of each recording 33.33 and $20.51 \%$, respectively.

\section{REFERENCES}

1. Abbott, W.S. 1925. A method of computing the effectiveness of an insecticide. J. Econ. Ent., 18: 265-277.

2. Abd El-Naby, M., R. M. Farrag and F. M. El-Sheikh. 1988. Biological effects of two insect growth regulators on the Egyptian cotton leafworm, Spodoptera littoralis (Boisd.). J. Agric. Sci. Mansoura Univ., 13 (1): 328-333.

3. Duncan, D. B. 1955. Multiple range and multiple F-test. Biomerics, 11: 1-42.

4. El-Defrawi, F. K., A. Toppozada, N. Mansour and M. Zeid 1964. Toxicological studies on the Egyptian cotton leafworm, Prodenia litura. 1. Susceptibility of different larval instar of Prodenia to insecticides. J. Econ. Ent., 57: 591-593.

5. Korkor, A. A., M.Z.F. Awad, A. M. Hamid and M. B. Abo-salem 1995. Screening of some insecticides against cotton leafworm and whitefly attaking cotton plants . Con. insect and Dev. Res., 7 us (50): 141 - 157

6. Mituis, T. 1985. Chitin synthesis inhibitors: Benzoylarylurea insecticides. Japan Pesticide Information, 47: 3-7. 
7. Moawad, G. M., Z. H. Zidan and F. E. El-Sweeki. 1996. Latent bio-insecticidal effects of certain soft nontoxic compounds on the cotton leafworm, Spodoptera littoralis (Boisd.) treated as eggs. Annals of Agric. Sci., Cairo, 1996, Special Issue, 255-264.

8. Mulder, R. and J. Gijswijt. 1973. The laboratory evaluation of two promising new insecticides which interfere with cuticle deposition. Pestic. Sci., 4: 737-745.

9. Shaaban, M. N. and E. I. Mourad. 1994. Effect of the insect growth inhibitor, flufenoxuron on the relative susceptibility of the cotton leafworm, Spodoptera littoralis (Boisd.). J. Agric. Sci. Mansoura Univ., 19 (4): 1561-1568.

10. Toppozada, A., S. Abdallah and M. G. El-Defrawi. 1966. Chemosterilization of larvae and adults of Egyptian cotton leafworm, Lrodenia littura by apholate, metapa and hempa. J. Econ. Entomol., 59: 1125-1128.

11. Zidan, Z. H., G. M. Moawad, S. A. Emara and F. E. El-Sweeki. 1996. Biological activities of certain non-toxic compounds against the cotton leafworm, Spodoptera littoralis (Boisd.). Annals of Agric. Sci., Cairo, 1996, Special Issue, 256-278. 


\title{
دراسة تأثير بيريروكسيفين، ديافنثيرون مقارنة بالمركب الطبيعي ميلبيتلتين علي السلالة المعملية لاودة ورق القطن
}

\author{
محسن محمد علي \\ معهر بحوث وقاية النباتات- مركز البحوث الزراعية - دقى - جيزة
}

أجريت الدراسـات المعمليـة لدراسـة التأثثر الأولـي والتأثثرالمتنقي وكذللك بعض التأثثرات الحيويـة

لأثثين من مانعات الإنسـلاخ (بيربروكسيفين، ديافنتيرون) وكذللك المركب الحيوي الطبيعي ميلبيتلتين علي العمر اليرقي السادس لدودة ورق القطن.

أثنتت النتائج أن التركيز الموصي بـه لمركب بيربروكسيفين كان الأكثر تأثيراً علي العمر اليرقي

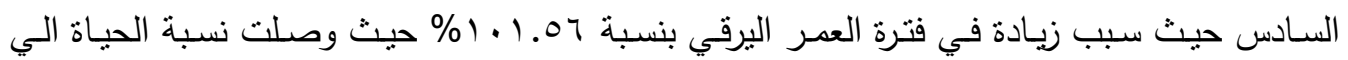

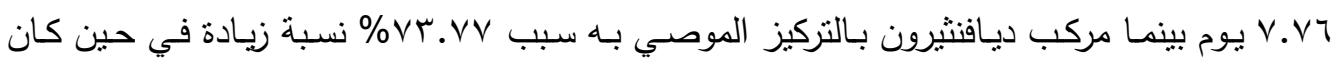
التركيز الحقلي لمركب ميلبيتلتين غير مؤثر علي طول العمر اليرقي. كذلك أدي مركب بيربروكسيفين بلين

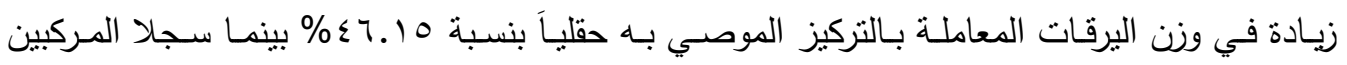

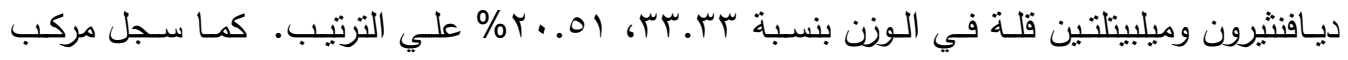

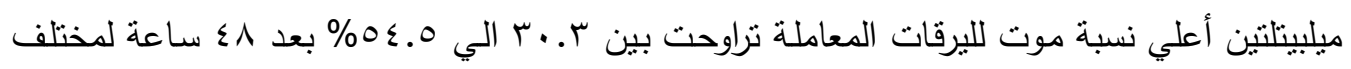

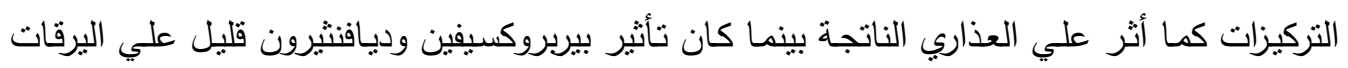

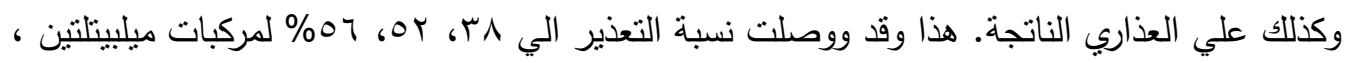

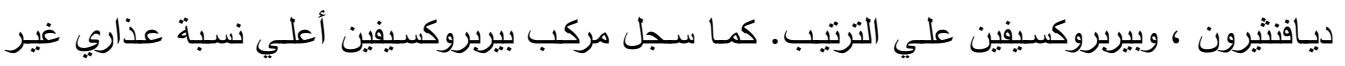

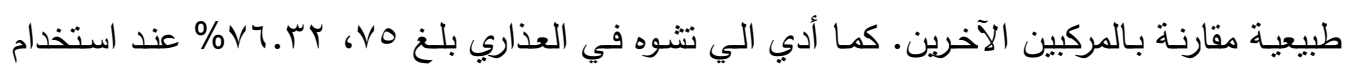

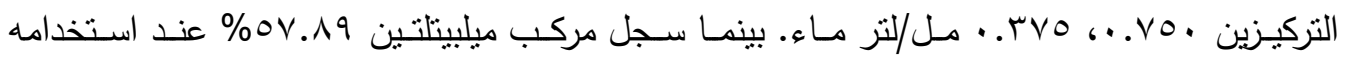

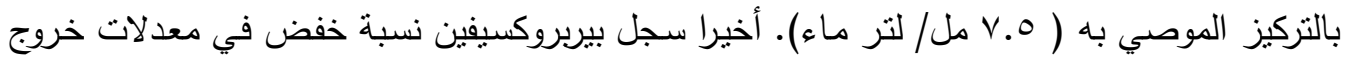

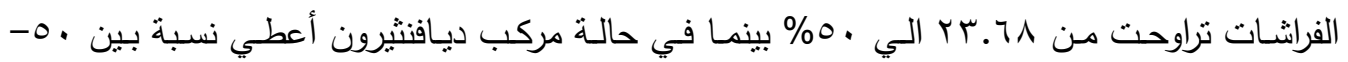

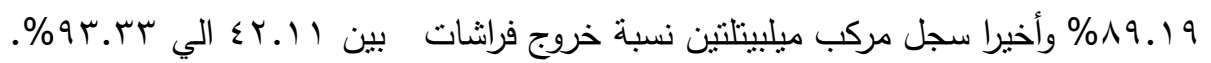

